\title{
Study of Some Ethno-Medicinal Wild Edible Plants Used for Several Strong Diseases in District Jashpur (Chhattisgarh)
}

\author{
Chandni Afsana ${ }^{1 *}$, Deepa Biswas ${ }^{2}$
}

${ }^{1}$ Research scholar, Department of Botany, Kalinga University, Naya Raipur (C.G.), India. ${ }^{2}$ Associate Professor, Department of Botany, Kalinga University, Naya Raipur (C.G.), India.

\begin{abstract}
Wild edible plants playing important role in the nutrition, hygien, medicinal and conventional lifestyles of the people. The area of Jashpur is rich biodiversity and tribal culture, dependent for sustenance on wild edible plants. These are not only consumed in the Jashpur area, but are also sold in local markets for the benefit of different sections of plants used in different types of diseases. The Survey was conducted on Jashpur district several villages where meeting with local medicine men, Baiga, Vaidya, local people and collect the data regarding to ethnomedicinal wild edible plants. In this study during field survey total 20 ethno medicinal wild edible plant species were identified which are used by the tribal or local people of Jashpur district Chhattisgarh. A total of 20 species belonging to 17 families were documented from the study area. Out of the recorded species were 5 herbs, 3 shrubs, 2 rhizome, 3 climbers, and the rest 7 were trees. Plant parts such as leaves, fruit, young twigs, shoots, rhizomes, roots, flowers, seeds, etc. These plants are also used for medicine as well as food people community.
\end{abstract}

Keywords: Nutrition, Traditional, Biodiversity, Ethnomedicinal, Community.

\section{INTRODUCTION}

Ethnobotany is the organized study of the relationship between plants and human. Many plants are edible and ethnomedicinal. These plants are used as food for curing various types of disease by reserved people and villagers. Jashpur district is very reach for their floristic bio-diversity. The significant tribes of Jashpur district are: Oraon/Kurunkh, Nagesia, Kanwar, Birhor, Baiga, Pahadi korwa and Munda, amongst which Oraon is the dominant tribe. The way of life of tribal people depends upon the land. Agriculture, fishing, collection of forest products, labour of any kind is their livelihood. Some tribal people of Jashpur area live in a very remote area where it is very difficult to get health related facilities; they live in the forest itself and used plants for their food and medicine.

The history of search for wild plants is as old as the history of civilization (1). Plants such as vegetables and fruits have good quality, satisfactory edible protein so that we can use them for nutritional value in food (2). Chhattisgarh is the only state of the country where about $44.2 \%$ (59772.2Heq) of the total area of state occupied by the forest (3). To research the distribution

*Address of Correspondence: Chandni Afsana, Research scholar, Department of Botany, Kalinga University New Raipur (C.G.), India. E-mail- chandniafsana7@gmail.com

(Received 02 October 2020; Revised 07 October 2020; Accepted 12 October 2020) 
pattern and ethno botanical usage of medicinal plants, the forest division of the northern hilly region of Chhattisgarh was surveyed. The proportion of Sal and the mixed forest in this state is more than that of the teak forest.

\section{OBJECTIVES OF THE PRESENT STUDY}

The main objectives of prepared these proposed research work is highlights the wild edible plants and there ethnomedicinal uses by tribal's in Jashpur district of Chhattisgarh the main objectives of the present study are follows:

- Study to survey the use of ethno medicinal wild edible plants among tribal people of entire Jashpur District.

- Documentations of ethno medicinal wild edible plants use by tribal's of Jashpur district Ethno botany openly means, all side of direct kinship of plants with human, Human has been using plants since time of his embossing on this planet. He receive the information becomes an integral part of his culture in India very old time mentions are there in Rig-Veda and Atharva Veda about the uses of plants.

A total 122 plant species from 94 genera and 56 families have been recorded as wild edible plants (4). In the last five decades, the genetic diversity of different crops and the extinction of forest species in the area have declined rapidly (5). There were 22 edible roots and tuberous plants belonging to different families, primarily used by Bastar tribes (6). 61 species of plants consisting of corms, tubers, leaves, flowers, fruits and seeds used by tribes, food recorded (7).

It is very necessary to have a suitable documentation of medicinal plants (8). 41 wild species from Northeast India that are used by ethnic communities as food supplements are reported (9). Wild food plants use common household food and make a significant contribution to the food security of the tribal people in many parts of the Pendra road (10). Fruits are a significant source of minerals, fiber and vitamins that provide important nutrients for human health (11). The requirement for food is mainly fulfilled by agriculture, but roots, tubers, leaves, flowers and forest fruits are also collected as supplementary foods (12). These publications cover not only wild edible plants, but also medicinal aspects that have already been documented, but there is a lack of accurate knowledge on food plants. This paper discusses plant species that are collected and consumed for food and medicinal purposes.

\section{MATERIAL AND METHODS}

\section{Study Area:}

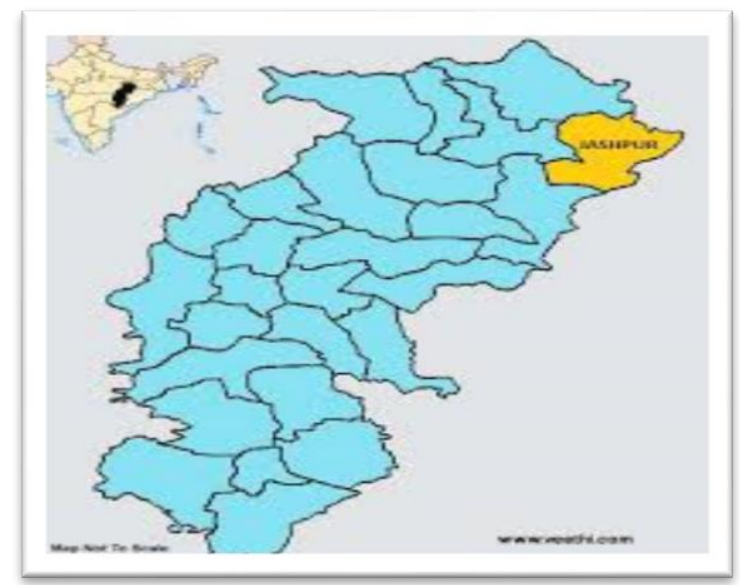

Figure 1: Chhattisgarh State Map

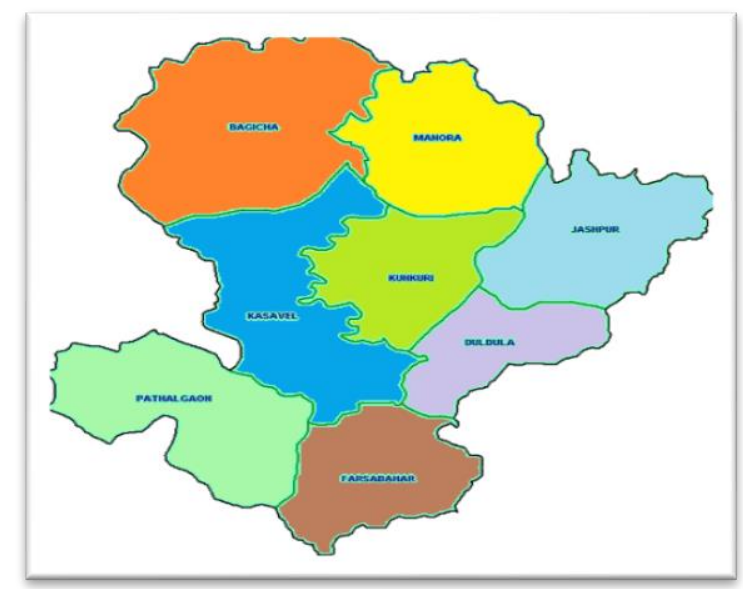

Figure 2: Jashpur District Map 
The present study area is mainly tribal areas and the economic structure of study area is based on agricultural activities and predominantly agrobased industry. It is situated in north-eastern corner of Chhattisgarh state in India and the three district of state (Balrampur, Sarguja and Raigarh) adjoining with Jashpur district. Jashpur district is located between 22017'north to 23015'north latitudes and 83030' east to 84024' east longitudes. Jashpur district has a total geographical area of 5838.00 sq.km. This study area has a north-south longitude of around $150 \mathrm{~km}$. And $85 \mathrm{~km}$ is its eastwest breadth.

The district having 8 tehsils and 8 CD blocks which are namely- Bagicha, Duldula, Jashpur, Kansabel, Kunkuri, Manora, Pathalgaon and Pharsabahar. The total 427 Gram Panchayats in Jashpur district, which is covering in all $8 \mathrm{CD}$ blocks. Geographically study area divided into two categories, the first is northern hilly belt which is called the upper Ghat and the second is southern part which is called Nichghat.

\section{Survey and collection of plant:} Ethnobotanical survey has been carried out in several villages or tribal areas in Jashpur district Chhattisgarh during January 2020 to August 2020. First-hand information on food plants was collected from experienced tribals, vaidyas and herbalist. There were a long list of plants but here only 20 plants are listed. The plants are classified by botanical name alphabetically, followed by local name, family, edible section, plant-using tribes, and habitat. Wherever the plants are eaten or used by tribals, the use of plants as food as well as medicinal purpose is given in brief.

The primary data will be acquired through schedule survey method whereas as a research tools the interview and observation method will also be used to obtain primary data from the head of some household of sample villages. The plants were assembled flowering and fruiting condition in the field. Photographs have taken on the spot and collected plant materials like flower, fruit, leaf or few leaves with twig, and root for herbarium preparation.

Identification of plant: The plant specimen were collected and identified by referring slandered local flora (Central Flora).

\section{RESULTS}

In this study during field survey total 20 ethno medicinal wild edible plant species were identified. Used by the tribal or local population of the Chhattisgarh district of Jashpur (Table 1). A total of 20 species from the study area belonging to 17 families were recorded. Herbs (5 in number), shrubs (4 in number), rhizomes (1 in number), climbers ( 3 in number), and the remaining 7 trees were among the reported organisms.

\section{DISCUSSION}

Plant parts such as leaves, berries, shoots, young twigs, roots, rhizomes, flowers, seeds, etc. are used by the tribal people culture for food or medicinal purposes, the plant taxa investigated have been described in tabular form along with the botanical name, local name, family, habitat and edible part and there have also been recorded medicinal uses by various parts of plants (Table-1). Tribal informants were consulted and given valuable information on wild edible plants and their utility for different nutritional and other purposes.

\section{CONCLUSION}

Different parts of plants are used by people for medicinal and for the purpose of eating in which leaves $(32 \%)$, fruits $(23 \%)$, stem $(7 \%)$, young stem $(2 \%)$, roots $(2 \%)$, rhizome $(4 \%)$, flowers $(11 \%)$, seeds $(14 \%)$, and whole plant (5\%). Most are collected by women, men and children. Some plant test are sweet However, some of the plant have side effect causing material are cause diarrhea, abdominal pain, and headache, constipation. Etc Although cultural norms and religion values play an important role in the conservation of wild edible plants, population pressure and its associated impact contribute much to the disappearance of the these plants. Thus community's participation is the suggested solution for the sustainable use and conservation of the wild edible plants in District Jashpur Chhattisgarh. 
Table 1: List of Ethno medicinal wild edible used by tribals of Jashpur district

\begin{tabular}{|c|c|c|c|c|c|c|}
\hline S.No & $\begin{array}{c}\text { Botanical } \\
\text { Name }\end{array}$ & $\begin{array}{l}\text { Local } \\
\text { Name }\end{array}$ & Family & $\begin{array}{l}\text { Plant } \\
\text { s } \\
\text { Habit }\end{array}$ & $\begin{array}{c}\text { Edible } \\
\text { part }\end{array}$ & Medicinal uses of plant \\
\hline 1 & $\begin{array}{l}\text { Amaranth } \\
\text { us viridus }\end{array}$ & $\begin{array}{l}\text { Cholai } \\
\text { Bhaji }\end{array}$ & $\begin{array}{l}\text { Amaranth } \\
\text { aceae }\end{array}$ & Herb & $\begin{array}{l}\text { Leaves } \\
\text { and } \\
\text { stems }\end{array}$ & fever, pain, asthma, diabetes \\
\hline 2 & $\begin{array}{l}\text { Amorphop } \\
\text { hallus } \\
\text { paeoniifoli } \\
\text { us }\end{array}$ & Zimikanda & Araceae & $\begin{array}{l}\text { Shrub } \\
\text { /Herb }\end{array}$ & $\begin{array}{l}\text { Stem } \\
\text { and } \\
\text { corms }\end{array}$ & $\begin{array}{c}\text { pain-killing, anti-inflammatory, } \\
\text { digestive, parasitic worms, } \\
\text { inflammation, coughs }\end{array}$ \\
\hline 3 & $\begin{array}{c}\text { Averrhoa } \\
\text { carambola }\end{array}$ & $\begin{array}{l}\text { Sweet star } \\
\text { fruit }\end{array}$ & $\begin{array}{c}\text { Oxalidace } \\
\text { ae }\end{array}$ & Tree & Fruits & $\begin{array}{l}\text { Leaves are applied externally in } \\
\text { the treatment of ringworm and } \\
\text { chickenpox. Roots are used to } \\
\text { treat muscle pain and } \\
\text { headaches. }\end{array}$ \\
\hline 4 & $\begin{array}{l}\text { Bauhinia } \\
\text { variegata }\end{array}$ & Kachnar & Fabaceae & Tree & $\begin{array}{l}\text { Leaves, } \\
\text { flower, } \\
\text { fruit and } \\
\text { seed }\end{array}$ & $\begin{array}{l}\text { Anti-bacterial, anti-fungal, anti- } \\
\text { malarial, pain reducing and } \\
\text { fever reducing. tumors, } \\
\text { wounds, cough, and bleeding } \\
\text { disorders }\end{array}$ \\
\hline 5 & $\begin{array}{l}\text { Bryophyll } \\
\text { um } \\
\text { pinnatum }\end{array}$ & $\begin{array}{c}\text { Patharchat } \\
\text { i }\end{array}$ & $\begin{array}{c}\text { Crassulace } \\
\text { ae }\end{array}$ & Herb & Leaves & $\begin{array}{c}\text { earache, burns, abscesses, ulcer, } \\
\text { insect bites, diarrhea and } \\
\text { Lithiasis }\end{array}$ \\
\hline 6 & $\begin{array}{l}\text { Buchanani } \\
\quad \text { a } \\
\text { cochinchin } \\
\text { ensis }\end{array}$ & Char & $\begin{array}{l}\text { Anacardia } \\
\text { ceae }\end{array}$ & Tree & Seed & $\begin{array}{l}\text { Roots are useful in treatment of } \\
\text { diarrhea. Leaves are used in the } \\
\text { treatment of skin diseases. } \\
\text { Fruits are used in treating cough } \\
\text { and asthma }\end{array}$ \\
\hline 7 & Cassia tora & Charota & $\begin{array}{c}\text { Caesalpina } \\
\text { ceae }\end{array}$ & Shrub & $\begin{array}{l}\text { Seeds, } \\
\text { leaves, } \\
\text { whole } \\
\text { plant }\end{array}$ & $\begin{array}{c}\text { It has been used for } \\
\text { treating skin like ringworm, } \\
\text { itching and psoriasis diseases, } \\
\text { snakebites. }\end{array}$ \\
\hline
\end{tabular}




\begin{tabular}{|c|c|c|c|c|c|c|}
\hline 8 & $\begin{array}{l}\text { Chenopodi } \\
\text { um album }\end{array}$ & Bhtua & $\begin{array}{l}\text { Chenopodi } \\
\text { aceae }\end{array}$ & Herb & $\begin{array}{l}\text { Seeds, } \\
\text { leaves, } \\
\text { shoot, } \\
\text { and } \\
\text { flowers. }\end{array}$ & $\begin{array}{l}\text { Leaves are applied to insect bite } \\
\mathrm{s} \text {, sunstroke, rheumatic joints an } \\
\mathrm{d} \text { swollen feet as a wash or poul } \\
\text { tice, while a decoction for cario } \\
\text { us teeth is used. } \\
\text { In treating urinary problems, th } \\
\text { e seeds are chewed and are } \\
\text { considered useful for relieving t } \\
\text { he discharge of semen through t } \\
\text { he urine. }\end{array}$ \\
\hline 9 & $\begin{array}{l}\text { Chorchoru } \\
\text { S olitorius }\end{array}$ & $\begin{array}{l}\text { Chech } \\
\text { bhaji }\end{array}$ & Tiliaceae & Herb & $\begin{array}{c}\text { Leaves } \\
\text { and seed }\end{array}$ & $\begin{array}{c}\text { Leaves are used for ascites, } \\
\text { pain, piles, and tumor, Cystitis, } \\
\text { dysuria, fever. }\end{array}$ \\
\hline 10 & $\begin{array}{l}\text { Citrullus } \\
\text { lantus }\end{array}$ & $\begin{array}{l}\text { Wild } \\
\text { melon }\end{array}$ & $\begin{array}{c}\text { Cucurbitac } \\
\text { eae }\end{array}$ & $\begin{array}{c}\text { Climb } \\
\text { er }\end{array}$ & $\begin{array}{l}\text { Leaves } \\
\text { flower } \\
\text { and fruit }\end{array}$ & $\begin{array}{c}\text { Seed are used in urinary } \\
\text { passages and bed wetting, seed } \\
\text { are used in paralyzes } \\
\text { tapeworms and roundworms. }\end{array}$ \\
\hline 11 & $\begin{array}{l}\text { Coccinia } \\
\text { Grandis }\end{array}$ & Kundru & $\begin{array}{c}\text { Cucurbitac } \\
\text { eae }\end{array}$ & $\begin{array}{c}\text { Climb } \\
\text { er }\end{array}$ & $\begin{array}{l}\text { Leaves } \\
\text { flower } \\
\text { and fruit }\end{array}$ & $\begin{array}{l}\text { In diabetes, roots and leaves are } \\
\text { used; plants are crushed and } \\
\text { externally applied to infected } \\
\text { regions to relieve headache pain } \\
\text { and rheumatism. }\end{array}$ \\
\hline 12 & $\begin{array}{l}\text { Colocasia } \\
\text { esculenta }\end{array}$ & Arbi & Araceae & $\begin{array}{l}\text { Rhizo } \\
\text { me }\end{array}$ & $\begin{array}{l}\text { Leaves } \\
\text { and } \\
\text { rhizome }\end{array}$ & $\begin{array}{l}\text { Plant is use for several disease } \\
\text { asthma, arthritis, diarrhea, } \\
\text { internal hemorrhage, } \\
\text { neurological disorders, and skin } \\
\text { disorders }\end{array}$ \\
\hline 13 & $\begin{array}{l}\text { Diospyros } \\
\text { melanoxyl } \\
\text { on }\end{array}$ & Tendu & Ebenaceae & Tree & Fruits & $\begin{array}{l}\text { Bark decoction is used in the } \\
\text { treatment of diarrhea, dried } \\
\text { flowers is useful in urinary, } \\
\text { skin and blood diseases. }\end{array}$ \\
\hline 14 & $\begin{array}{l}\text { Emblica } \\
\text { oficinalis }\end{array}$ & Amla & $\begin{array}{l}\text { Euphorbia } \\
\text { ceae }\end{array}$ & Tree & Fruits & $\begin{array}{l}\text { It is used to reinforce teeth, hair } \\
\text { and nails, as well as to regulate } \\
\text { sugar in the blood. It is also } \\
\text { used for bleeding, } \\
\text { haemorrhoids, anaemia, } \\
\text { diabetes, diarrhoea, dysentery, } \\
\text { jaundice anaemia, and }\end{array}$ \\
\hline
\end{tabular}




\begin{tabular}{|c|c|c|c|c|c|c|}
\hline & & & & & & dyspepsia. \\
\hline 15 & $\begin{array}{l}\text { Madhuca } \\
\text { longifolia }\end{array}$ & Mahua & $\begin{array}{c}\text { Sapotacea } \\
\text { e }\end{array}$ & Tree & $\begin{array}{l}\text { Fruits, } \\
\text { flower } \\
\text { and } \\
\text { leaves }\end{array}$ & $\begin{array}{l}\text { Mahua flower bearing cycle is } \\
\text { March-April. The flower sheds } \\
\text { at dawn as it becomes mature. } \\
\text { New mahua flowers contain } \\
\text { various phytochemicals and are } \\
\text { sweet in taste. The fresh } \\
\text { flowers are usually picked and } \\
\text { dried under direct sunlight for } \\
\text { 2-3 days and placed in gunny } \\
\text { bags in natural surroundings. }\end{array}$ \\
\hline 16 & $\begin{array}{c}\text { Marsilea } \\
\text { quadrifolia }\end{array}$ & $\begin{array}{l}\text { Water } \\
\text { clover }\end{array}$ & $\begin{array}{c}\text { Marsileace } \\
\text { ae }\end{array}$ & Herb & $\begin{array}{c}\text { young } \\
\text { stem and } \\
\text { leaves }\end{array}$ & $\begin{array}{l}\text { The plant is anti-inflammatory, } \\
\text { diuretic, depurative, febrifuge } \\
\text { and refrigerant, the plant is also } \\
\text { applied externally in the } \\
\text { treatment of snakebites and skin } \\
\text { injuries, including abscesses. }\end{array}$ \\
\hline 17 & $\begin{array}{l}\text { Momordic } \\
\text { a dioica }\end{array}$ & Kheksa & $\begin{array}{c}\text { Cucurbitac } \\
\text { eae }\end{array}$ & $\begin{array}{c}\text { Climb } \\
\text { er }\end{array}$ & $\begin{array}{l}\text { Fruit, } \\
\text { shoot, } \\
\text { leaves } \\
\text { and } \\
\text { roots }\end{array}$ & $\begin{array}{l}\text { In bleeding piles and urinary } \\
\text { problems, they are added. As a } \\
\text { vegetable, the tuberous root is } \\
\text { cooked and root paste is spread } \\
\text { over the body as a fever } \\
\text { sedative. }\end{array}$ \\
\hline 18 & $\begin{array}{c}\text { Osmium } \\
\text { tenuifloru } \\
\mathrm{m}\end{array}$ & Basil & Lamiaceae & Herb & $\begin{array}{l}\text { whole } \\
\text { plant }\end{array}$ & $\begin{array}{l}\text { In the Ayurvedic tradition, a } \\
\text { pungently herbal, warming, } \\
\text { antiseptic herb is a very } \\
\text { essential herb; it causes } \\
\text { swelling; reduces fevers; } \\
\text { relaxes spasms; relieves pain; } \\
\text { prevents bacterial infections; } \\
\text { improves the immune and } \\
\text { nervous systems; reduces } \\
\text { inflammation; and helps the } \\
\text { digestive system. }\end{array}$ \\
\hline 19 & $\begin{array}{l}\text { Physalis } \\
\text { angulata }\end{array}$ & Chirpoti & $\begin{array}{c}\text { Solanacea } \\
\mathrm{e}\end{array}$ & Herb & $\begin{array}{c}\text { Leaves } \\
\text { and } \\
\text { fruits }\end{array}$ & $\begin{array}{l}\text { The leaves have been used to } \\
\text { treat diseases of the stomach. } \\
\text { The plant is used to promote } \\
\text { reproduction in the Pacific }\end{array}$ \\
\hline
\end{tabular}




\begin{tabular}{|c|c|c|c|c|c|c|}
\hline & & & & $\begin{array}{c}\text { Islands; to treat infertility in } \\
\text { women; and to treat dengue } \\
\text { fever. The leaves are analgesic, } \\
\text { diuretic, relaxant and } \\
\text { parasiticidal. }\end{array}$ \\
\hline 20 & $\begin{array}{c}\text { Schleicher } \\
\text { a oleosa }\end{array}$ & Kosam & $\begin{array}{c}\text { Sapindace } \\
\text { ae }\end{array}$ & Tree & $\begin{array}{c}\text { Leaves } \\
\text { and fruit }\end{array}$ & $\begin{array}{c}\text { The oil obtained from the seed } \\
\text { is applied externally in herbal } \\
\text { medicine to treat itching, acne } \\
\text { and other skin problems. To } \\
\text { treat vomiting and stomach } \\
\text { issues, leaf decoction is made. }\end{array}$ \\
\hline
\end{tabular}

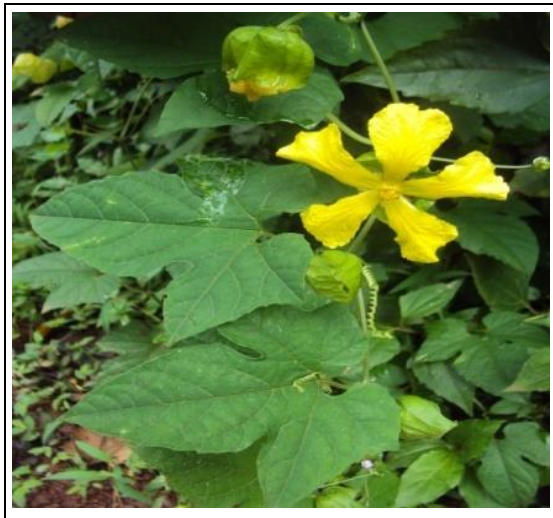

Figure 3: Momordica dioica

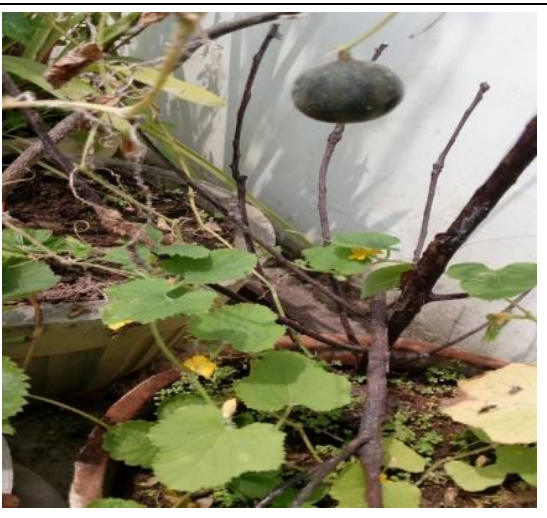

Figure 4: Citrullus lantus

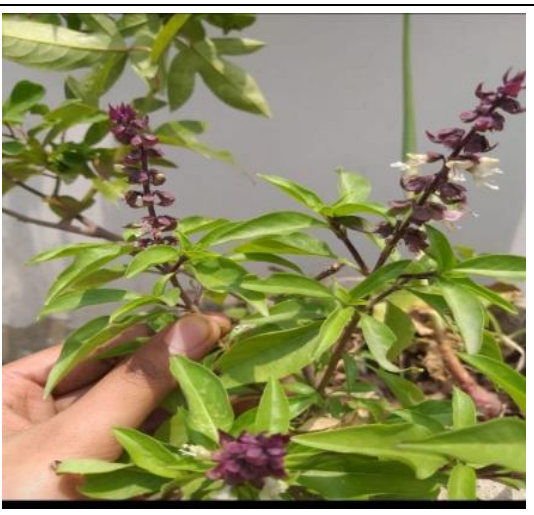

Figure 5: Osmium tenuiflorum

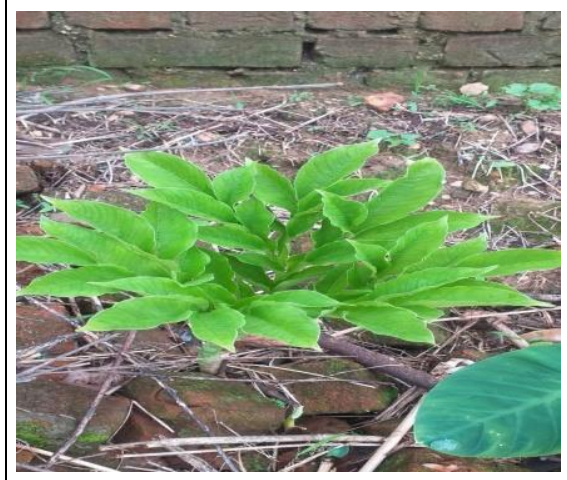

Figure 6: A. paeoniifolius

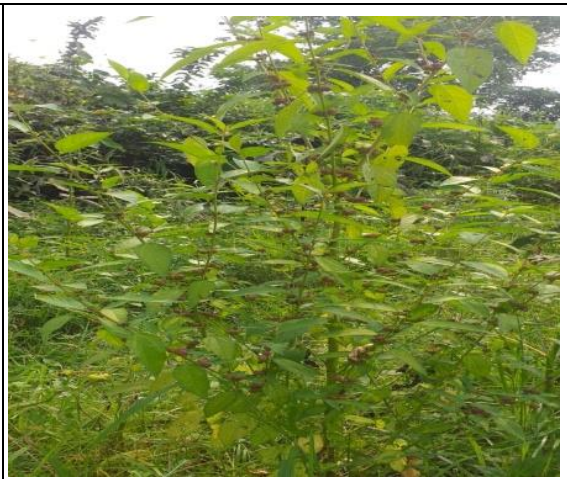

Figure 7: Chorchorus olitorius

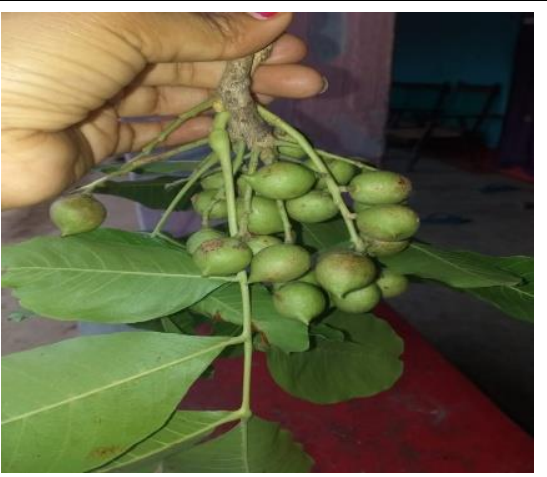

Figure 8: Schleichera oleosa 


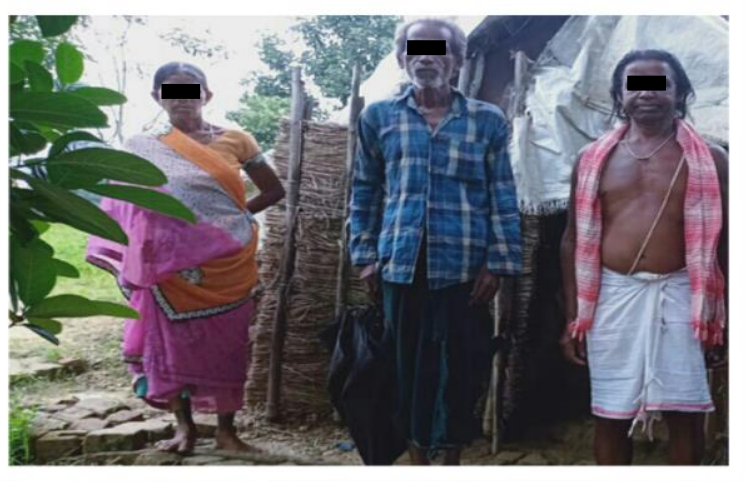

Figure 9: Tribal's Photograph taken by researcher (me) from Gala village, block Pathalgaon, District Jashpur

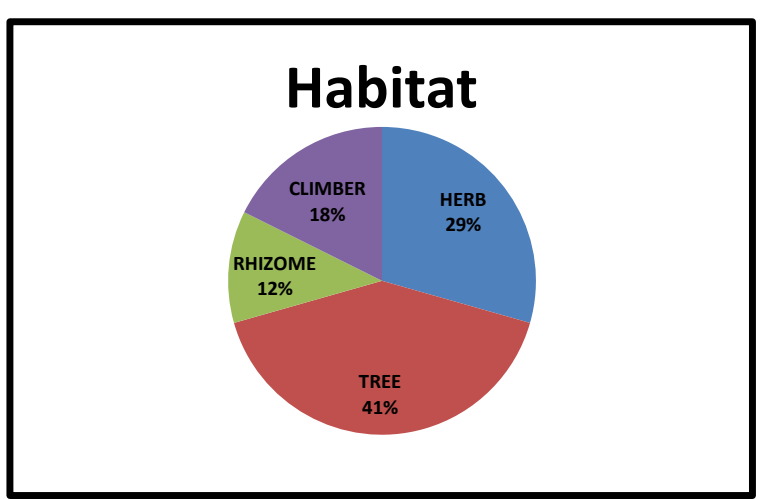

Figure - 10: Percentage of different plants habit collected in Jashpur district.

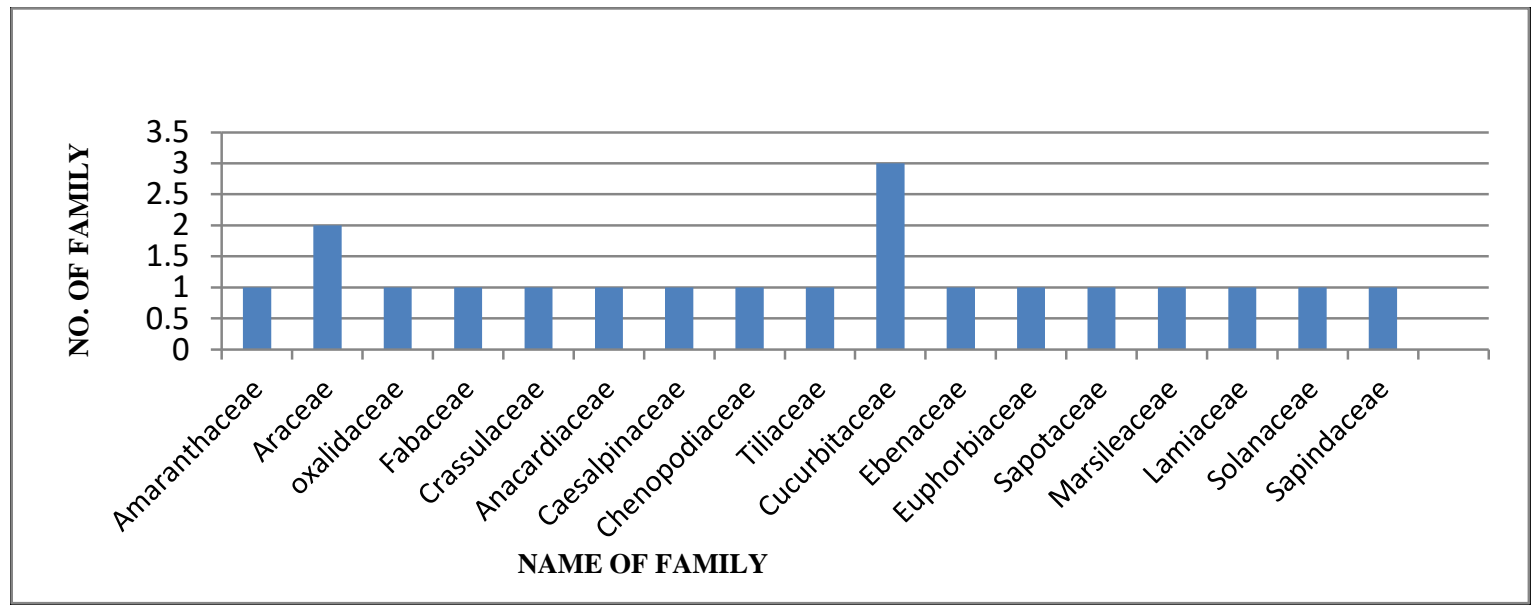

Figure- 11: Distribution of family of Ethno- medicinal edible plants found in study area

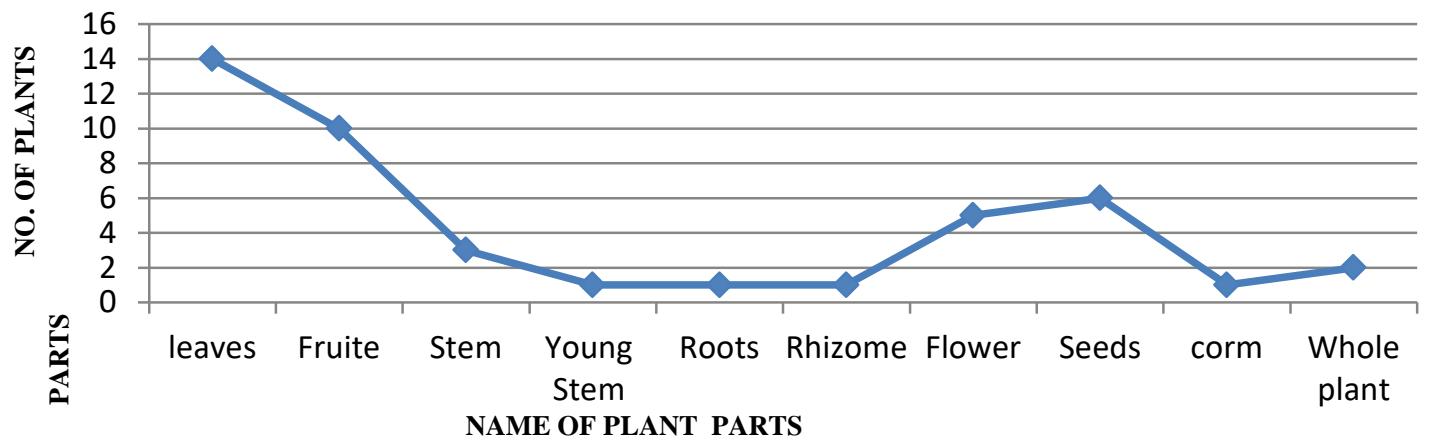

Figure- 12: Number of edible parts of the plants 


\section{ACKNOWLEDGEMENT}

The author is grateful to herbalist, tribal's and nontribal's person who helped us by sharing the valuable information of their traditional herbal knowledge and I would like to thanks my guide for their valuable guidance. I also thankful to my colleague and friends who helped me in making this research paper.

\section{CONFLICT OF INTEREST}

There is no conflict of interest in this present study. This research work is not a part of any other studies and it is our original work.

\section{REFERENCE}

1. Shrivastava M. Study of some wild edible plants of Bastar District with special reference to Muriya Tribes. Indian J. Applied \& Pure Bio. 2016; 31(1): 23-26.

2. Ali A, Deokule SS. Studies on Nutritional Values of Some Wild Edible Plants from Iran and India. Pakistan Journal of Nutrition. 2009; 8(1): 26-31.

3. Sinha MK. Medicinal plants used among the tribals of manendragarh block (Koriya District) C.G. Journal of medicinal plants studies. 2017; 5(6): 114-119.

4. Padhan B, Panda D. Wild Edible Plant Diversity and its Ethno-medicinal use by Indigenous Tribes of Koraput, Odisha, India. Research Journal of Agriculture and Forestry Sciences. 2015; 3(9): 1-10.

5. Nayar MP, Singh AK and Nair KN, Agrobiodiversity hotspots in India. Conservation and benefit sharing. PPV and FR Authority, New Delhi. 2009; 2: 217.
6. Banik A, Nemaand S, Shankar D. Wild edible fuber and root plants available in Bastar region of Chhattisgarh. International journal of forestry and cropimprovement. 2014; 5(2): 85 89.

7. Reddy BM, Wild edible plant of chandarpur district maharastra, India. Indian journal of natural products and resources. 2012; 3(1): 110-117.

8. Mishra SB, Dwivedi S, Shashi A, Prajapati K. Ethnomedicinal Uses of Some Plant Species by Ethnic and Rural Peoples of the Salem District of Tamilnadu with Special Reference to the Conservation of Vanishing Species. Ethnobotanical Leaflets. 2008 12: 873-87.

9. Deb D, Sarkar A, Barma BD, Datta BK, Majumdar K. Wild edible plants and their utilization in traditional recipes of Tripura, Northeast India. Advances in Biological research. 2013; 7(5):203-211.

10. Sharma M, Sharma RP, Sharma A. Ethnomedicinal edible wild plants of Pendra road, forest region of Chhattisgarh. International Journal of Botany Studies. 2017; 2 (3): 29-33.

11. Ali A, Deokule SS. Studies on Nutritional Values of Some Wild Edible Plants from Iran and India. Pakistan Journal of Nutrition. 2009; 8(1): 26-31.

12. Ekka, A. Some Ethenomedicinally important and rare plants of north-east Chhattisgarh India. International Journal of Advance Research in Science and Engineering. 2016; 5(10): 127-131. 